\title{
Sīrāf: a Sasanian port
}

\author{
DAVID WHITEHOUSE
}

\begin{abstract}
For the past five years the British Institute of Persian Studies, supported by the British Museum, the Calouste Gulbenkian Foundation and other institutions, has been excavating the site of Siräf, on the Iranian coast of the Persian Gulf. Dr David Whitehouse here describes how his excavations have established that Siräf was already a port in the Sasanian period, indeed that it was the port of Gür, and reviews the evidence for Sasanian maritime trade.*
\end{abstract}

In the gth and Ioth centuries AD Siräf (FIG.I) was a leading entrepôt for the maritime trade which supplied the Middle East with merchandise from India, China, South East Asia and East Africa. Medieval writers, such as Iștakhrī, describe Siranf as a wealthy city with opulent multi-storey houses. The earliest documents which refer to Sirtaff belong to the gth century and one of the objectives of the excavation was to investigate the early, possibly pre-Islamic, development of the site. Last winter we fulfilled this objective by establishing that Sirāf was already a port in the Sasanian period. Here I shall describe the Sasanian remains and review the evidence for Sasanian maritime trade, a subject overshadowed by studies of the overland Silk Route from China to the cities of Western Asia (Bivar, 1970, with bibliography).

Accounts of the excavations at Sirāf have appeared annually in Iran (Whitehouse, I968; 1969; 1970a; 1971a), supplemented by a progress report on the first four seasons (Whitehouse, 1970b) and discussions of the domestic architecture (Whitehouse, I97Ib) and some of the pottery (Whitehouse, 1970c). The fifth Report will appear in Iran, x, (1972).

\section{THE EARLY ENCLOSURES}

In $1968-69$ we discovered that the platform supporting the Great Mosque concealed the remains of at least one large and well-preserved building (Whitehouse, I970, 8). The platform itself was completed in the early $9^{\text {th }}$ century and the eroded condition of some of the underlying structures suggested that they might be considerably older. The following year we removed a large part of the platform, revealing that the early complex consisted of two enclosures: an inner enclosure with a stout curtain wall and a fortified entrance and an adjoining outer enclosure containing more than $5^{\circ}$ rooms (Whitehouse, I971a, 4-5). Last winter we enlarged the excavation and began to investigate the history of the enclosures by dismantling some of the latest walls and floors (PL. XL, FIG. 2).

Both enclosures stood on the shore. The inner enclosure emerges as a fort or fortified palace. If symmetrical, it was $62 \mathrm{~m}$. square, with towers $5 \mathrm{~m}$. across at the angles (PL. XLb). An entrance occupied the centre of the south side, flanked by semi-circular towers (PL. XLa). Inside the entrance was a rectangular gatehouse, while a range of rooms lined the curtain wall, presumably on all four sides. In general terms, the building recalls the smaller Umayyad strongholds, such as Qasr al-Hair ash-Sharqi in Syria (Creswell, $1969,1 / 2,522-28$ ). The outer enclosure, which measured more than $35 \times 70 \mathrm{~m}$., was entirely different: a rambling

* The author is indebted to the Iranian Archaeological Service for granting him a permit to work at Siraf and to the Director of the British Institute of Persian Studies, Mr David Stronach, for his assistance in Iran. The photographs used in PLS. XL and XLI were taken by Pauline Farnworth and Joseph Cloutman and printed by Giles Sholl. 
SIRAF: A SASANIAN PORT

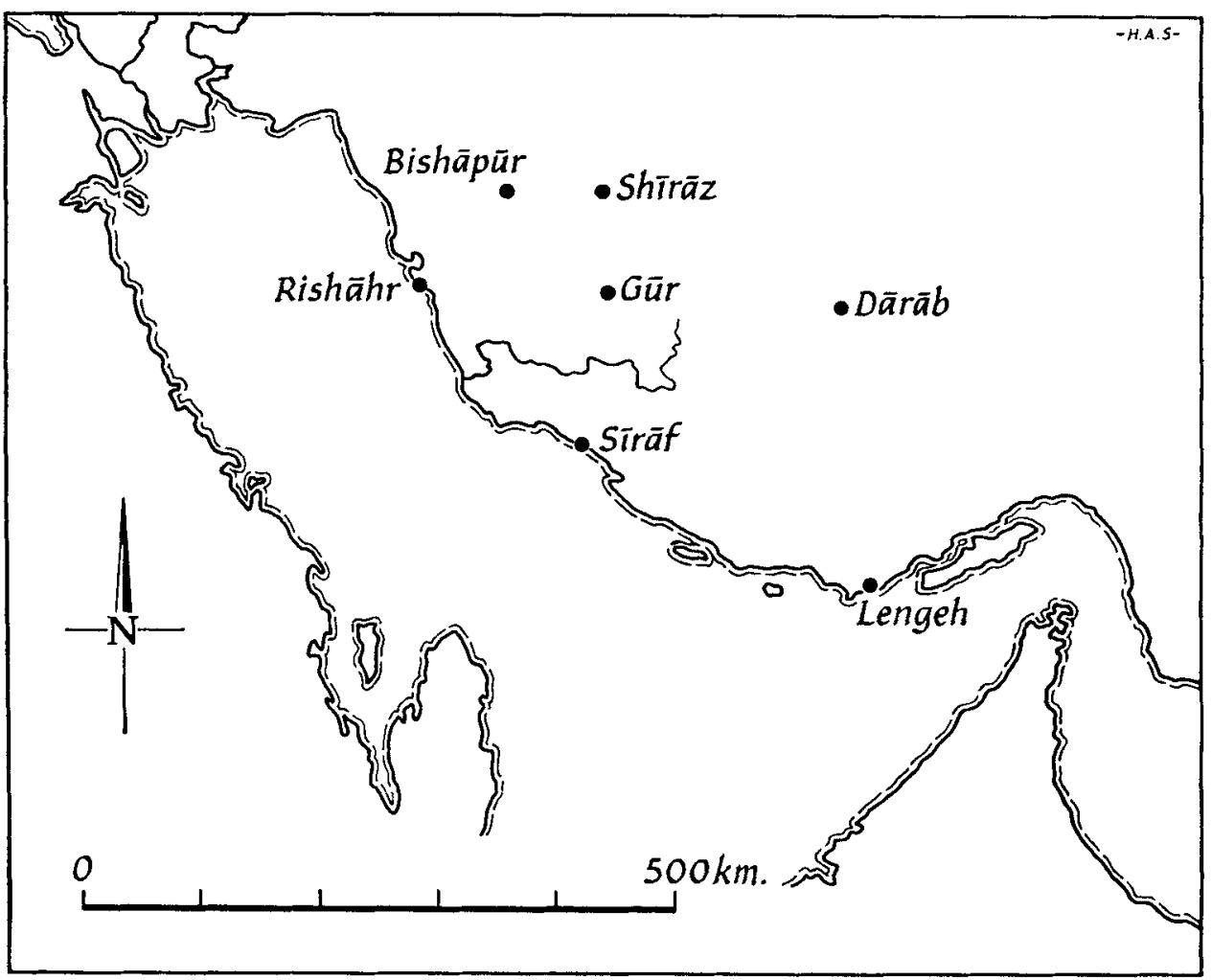

Fig. I. Map of the Persian Gulf

warren of rooms traversed by narrow passages and protected by a simple curtain wall (PL. XLC). The outer enclosure may be seen as a settlement or, more probably, one quarter of a settlement surrounding the fort.

The outer enclosure contained at least four periods of construction. Period 4 was associated with lead coins of the 8th or early 9th century and without doubt was Islamic. Among the finds sealed by the floors of Period 3 was a solidus of Constans II (64I-68), struck at Constantinople in $65 \mathrm{I}-59$. Without exception, the few coins from Periods $I$ and 2 were Sasanian and we found nothing that was certainly Islamic. If, as we conclude, the earliest phase(s) of the outer enclosure are Sasanian, it is highly probable that the fortress, too, is of Sasanian origin. Indeed, in the 8th century the fort was already redundant; buildings ran right up to the walls making it barely defensible, for not only did they obscure the defenders' field of fire but also afforded cover to attackers bent on sapping or storming the gate.

\section{OTHER SASANIAN FINDS}

The buildings beneath the mosque are not the only structures which appear to be Sasanian. Investigation of the western defences, which reinforced the bank of a seasonal torrent known as Kunārak, yielded three coins from primary contexts, all Sasanian (see the map of Sirāf in Stein, 1937, plan 17 , reproduced in Whitehouse, I968, fig. 2 and I969, fig. I). The defences are $\mathbf{I} \cdot \mathbf{\mathrm { km }}$. from the Great Mosque, suggesting that the Sasanian settlement lay in a walled enclosure more than $\mathrm{I} \mathrm{km}$. across. Within this area, the earliest deposits at Site $\mathrm{F}$ again yielded three Sasanian coins-and not a single definite Islamic object (Whitehouse, 1971, I0), while stray Sasanian coins occur in Islamic deposits at 


\section{ANTIQUITY}

Sites C, D, E and K. All told, we have $2 \mathrm{r}$ Sasanian coins from Sirāf, and several other finds of Sasanian date. The platform of the Great Mosque, for example, contained a coin of Theodosius I (376-94) (PL. XLI $b$ ), one of the few Roman coins reported from the Persian Gulf (for another, see Ghirshman, I960, 5) and several Sasanian seals. Elsewhere in the mosque we found one-and possibly a second-potsherd bearing a Pahlavi graffito. In spring I97I, after we had left the site, it is reported that a cache of more than $3^{\circ}$ stone seals was found 'at or near Sirāf'. To judge from plasticine impressions, most of the seals are pre-Islamic; one bears a Pahlavi inscription, while a second is engraved in Roman style. If the seals were found at Sirāf, they add considerable weight to the evidence for a Sasanian settlement.

Finally, Sīrāf possesses several cemeteries of chamber tombs, hewn in vertical-sometimes barely accessible-cliffs. The tombs are small, seldom more than $2 \mathrm{~m}$. across, and may contain a rock-cut bench. The entrances, when wellpreserved, are rectangular, sometimes set in a recessed panel which was plastered white (PL. XLIC). None of the accessible tombs is intact, although some retain a scatter of unburnt bones. Clearly, the tombs are not Islamic and I suggest that they are Zoroastrian ossuaries intended to receive the bones after exposure of the corpse. While Islamic Sirāf may have contained a Zoroastrian community, the presence of Sasanian remains elsewhere on the site suggests that many, if not all, the tombs are Sasanian.

To summarize, the evidence for Sasanian occupation at Sirāf consists of: the earliest phase(s) of the enclosures beneath the Great Mosque; the earliest phase of the city wall; the chamber tombs; Sasanian coins from the earliest deposits at Site F; a scatter of coins elsewhere on the site; at least one Pahlavi graffito; several Sasanian seals; a Roman coin, and perhaps also the cache of seals allegedly found in or near Siräf. We should note, too, that the gth-century writer Baladhuri records in the Kìtāb Futūh al-Buldān (trans. Murgotten F. I924 [New York] II, 134-35) the capture of a Sasanian castle at Siräf, Suryanj or Shuhriyäj during the muslim conquest of Fārs. If this is indeed our site, which is by no means certain, the castle might be the fortress under the mosque. However, even without Balādhurī and the cache of seals, the evidence establishes beyond reasonable doubt that Siräf already existed in the Sasanian period.

\section{DISCUSSION}

Granted that Siräf was a Sasanian settlement, perhaps more than $\mathbf{I ~ k m}$. across, its function is clear; it was the port of Gūr, the Sasanian city $90 \mathrm{~km}$. south of Shirāz. Reputedly rebuilt c. 226 by Ardashir I, the founder of the Sasanid dynasty, Gūr (which was renamed Fïrüzābād by the Buyid ruler Adud ad-Dawla), was one of the principal cities of Fārs, contained within circular defences $2,240 \mathrm{~m}$. across (Stein, I936, I 17 ). The easiest itinerary between Gūr and the coast is the route to Siräf. This route was certainly in use by the tenth century, when Siräfì caravans bound for Shīrāz travelled via Jam, Pas-i Rūdak and Fìrūzābād (Aubin, 1969, 27), and Vanden Berghe (I96I, I72-98) describes as Sasanian several monuments along its course.

It comes as no surprise that Gūr possessed a port. Among I 8 cities allegedly built or rebuilt by Ardashir I and listed by the roth century writer Hamza of Issfahān, no fewer than II are ports and clearly the Sasanians were a leading maritime power. Indeed, Sasanian merchants traded with East Africa, India and Ceylon. The evidence for their activity is scattered and in the paragraphs which follow I have drawn extensively on the enthusiastic study of Hadi Hasan and the researches of Wolters, Tibbetts and Colless.

We hear first of a Sasanian fleet in the Persian Gulf c. 326 when, according to Tabarī, Shāpūr II attacked the Arabian coast after raiders of Bahrrain and Hajār had plundered Rishāhr and the coast of Fārs (Hadi Hasan, 65). Farther afield, the $4^{\text {th }}$ century writer Palladius refers to Sasanian vessels in the Indian Ocean (Tibbetts, 6), while the Greek version of the Martyrdom of St Arethas records Sasanian trade with Axum in East Africa in the late $5^{\text {th }}$ or 6th century (Wolters, I4I). Cosmas Indicopleustes (XI, 337) 

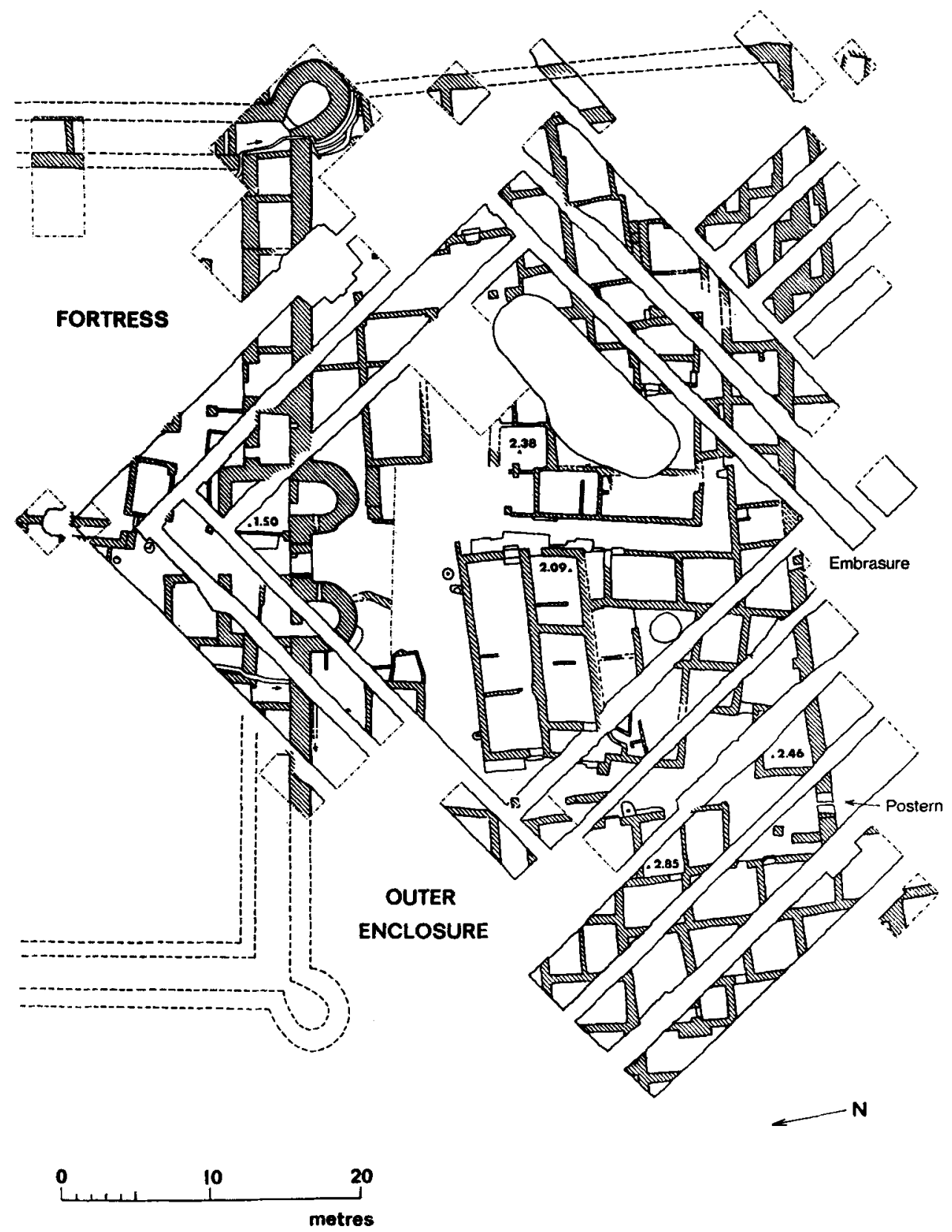

Fig. 2. Sìrāf : Sasanian buildings beneath the great Mosque 


\section{ANTIQUITY}

reports the existence of a large Sasanian colony in Ceylon in 522 and several muslim writers, notably Tabari, state that Chosroes I (53I-79) attacked the island as a reprisal for the maltreatment of Persian settlers. Procopius (Bello Persico, $\mathrm{xx}, \mathrm{1} 2$ ), again writing of the 6th century, complains that Sasanian merchants had cornered the market in silk exported from Indian harbours. Indeed, it appears that Sasanian traders concentrated their activities in India and Ceylon. Nevertheless, merchants and settlers did venture farther east; Syriac sources record the presence of Persian christians in the East Indies c. $65^{\circ}$ (Colless, $\mathrm{II}$ ) and Chinese documents refer to Poss $\breve{u}$ (by which they probably, but not certainly, mean Persian) merchants and merchandise, beginning in the 6th century (Wolters, 262-84). Thus, in 671 the Chinese I-Tsing sailed from Canton with a Possur captain and Hui-Ch'au, who travelled in India in 727, writes that the Persians used to sail to Ceylon, K'un-lun (probably part of the Malay archipelago) and Canton, seeking gold, silk and other goods. The Umayyad caliphs did not encourage maritime trade and so these references, although later in date than the muslim conquest of Persia, probably reflect a pattern established by the Sasanians. Among the material evidence of trade between Persia and the east, we have Sasanian (and numerous Roman) genes from the port of Oc-Eo in the Mekong delta (Coedès) and Sasanian glass from
China, Korea and Japan (Pinder Wilson). While some of the glass probably was carried overland, the finds from Oc-Eo undoubtedly arrived by sea, either in Sasanian ships or, more probably, in eastern convoys trading with middlemen in Ceylon.

The reference to christians in the East Indies deserves comment, for Nestorians may have played a significant part in Sasanian maritime trade. Cosmas, himself a Nestorian, reports that the Persian settlers in Ceylon were christian and the I Ith-century Chronicle of Seert states that the Sasanian ruler Yazdagird I (399-421) sent the head of the Nestorian church, Ahai, to Fārs to investigate the piracy of ships returning from India and Ceylon (Colless, 18). If a Nestorian seemed best suited to the task, perhaps the merchants of Färs included Nestorians. In the Persian Gulf, several cities, including Rishāhr, were the seats of bishops and Kharg Island supported a Nestorian community (Ghirshman).

Rishāhr, like Sīrāf, may have been the port of a major Sasanian city: Bishāpūr, $95 \mathrm{~km}$. west of Shīrāz. Both Rishāhr and Bishāpūr reputedly were built or rebuilt by Shāpūr I (24I-72). It would be interesting to investigate the possibility that a third Sasanian city in Fārs, Dārāb, $225 \mathrm{~km}$. south-east of Shirãz, also possessed a port, either in the vicinity of Bandar 'Abbās or, more probably, near Bandar-i Lengeh, $275 \mathrm{~km}$. south-east of Sirāf.

\section{BIBLIOGRAPHY}

AUbiN, J. I969. La Survie de Shīlāu et la route du Khunj-ō-Fāl, Iran, vII, 21-38.

Brvar, A. D. H. r970. Trade between China and the Near East in the Sasanian and early Muslim periods, in Watson W. (ed.), Pottery and metalwork in T'ang China (hereafter $P M T C$ ), (London), $x-8$.

COEDis, G. 1947. Fouilles en Cochinchine: le site de Go Oc Eo, ancien port du royaume de Fou-Nan, Artibus Asiae, x, 193-9.

COlless, B. E. I969. Persian merchants and missionaries inmedieval Malaya, Fournal of the Malaysian Branch of the Royal Asiatic Society (FMBRAS), $\mathrm{XIII} / 2, \mathrm{ro}-47$.

CRESWELL, K. A. C. 1969. Early muslim architecture, and ed. (Oxford)

HASAN, H. 1928. $A$ history of Persian navigation (London)
GHIRSHMAN, R. 1960. The island of Kharg (Tehran). PINDER WILSON, R. I970. Glass in Asia during the T'ang Period, $P M T C, 62-7 \mathrm{I}$.

STEIN, A. 1936. An archaeological tour in the Ancient Persis, Iraq, III, I I I-225.

1937. Archaeological reconnaissances in North Western India and South Eastern Asia (London). TIBBETTS, G. R. I957. Early muslim traders in South East Asia, $\mathscr{Y} M B R A S, \mathrm{xxx} / \mathrm{I}, \mathrm{I}-45$.

VANDEN BERGHE, L. I 96I. Récentes découvertes de monuments Sassanides dans le Fārs, Iranica Antiqua, r, 163-98.

Whitehouse, D. 1968. Excavations at Sïrāf. First interim report, Iran, $\mathrm{v1}, \mathrm{I}-22$.

r969. Excavations at Sīräf. Second interim report, Iran, vIr, 39-62.

1970a. Excavations at Sīräf. Third interim report, Iran, VIII, I-I8. 
I970b. Sīrāf: a medieval port on the Persian Gulf, World Archaeology, 2/2, 141-58.

r970c. Some Chinese and Islamic Pottery from Sïrāf, $P M T C, 3^{\circ}-33$.

I971 I. Excavations at Sïrāf. Fourth interim report,

Iran, IX, I-I 8 . r97xb. The houses of Sīrāf, Iran, Archaeology, $24 / 3,255-62$

WOLTERS, O. W. 1962. Early Indonesian commerce and the origins of Srivijaya (unpublished $\mathrm{PhD}$ thesis, University of London).

\section{The International Series of Monographs on Science in Archaeology No. 1 \\ Study \\ of Animal \\ Bones from \\ Archaeological Sites \\ R. E. Chaplin \\ August 1971, $X+170$ pp., $£ 2.00$ \\ Contents: Structure and biological properties of bone. Planning and organisation of bone studies. Bone identification and the establishment of reference collections. Techniques for the study of site collections. Age determination from bones. The use of measurements. The determination of sex from bones. Bone pathology. The interpretation of bone evidence. Animal remains as indicators of past environments. References.}

SEMINAR PRESS London and New York 24-28 Oval Road, London NW1 7DX, England 111 Fifth Avenue, New York, NY 10003, USA

l'archéologie dans le monde et toute ce qui concerne les recherches historiques, artistiques et scientifiques sur terre et dans les mers

free copy on request 

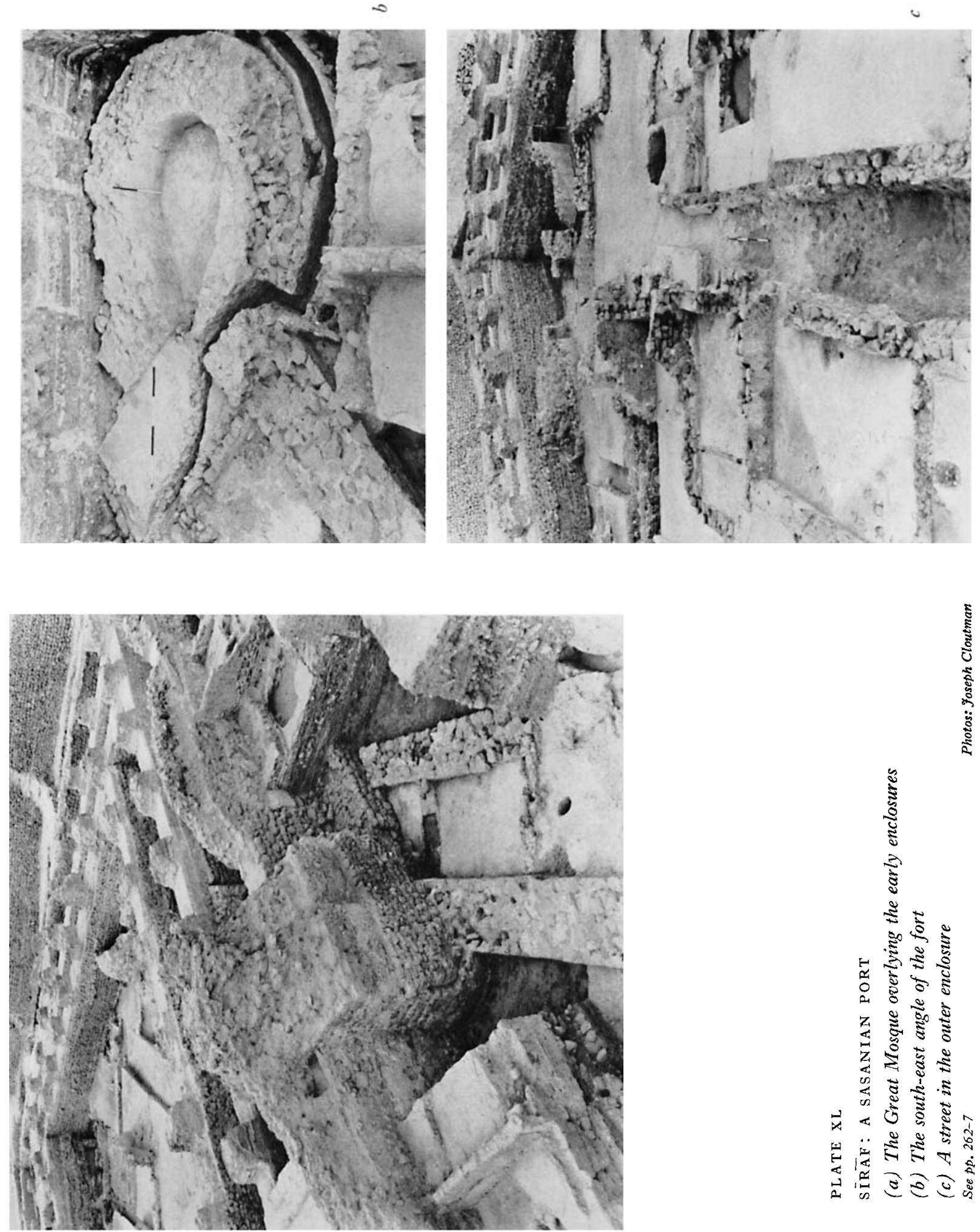

ปัँ

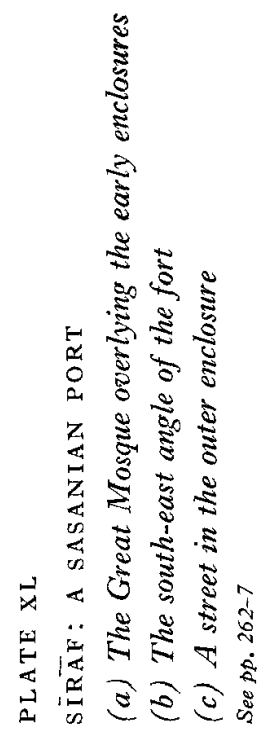



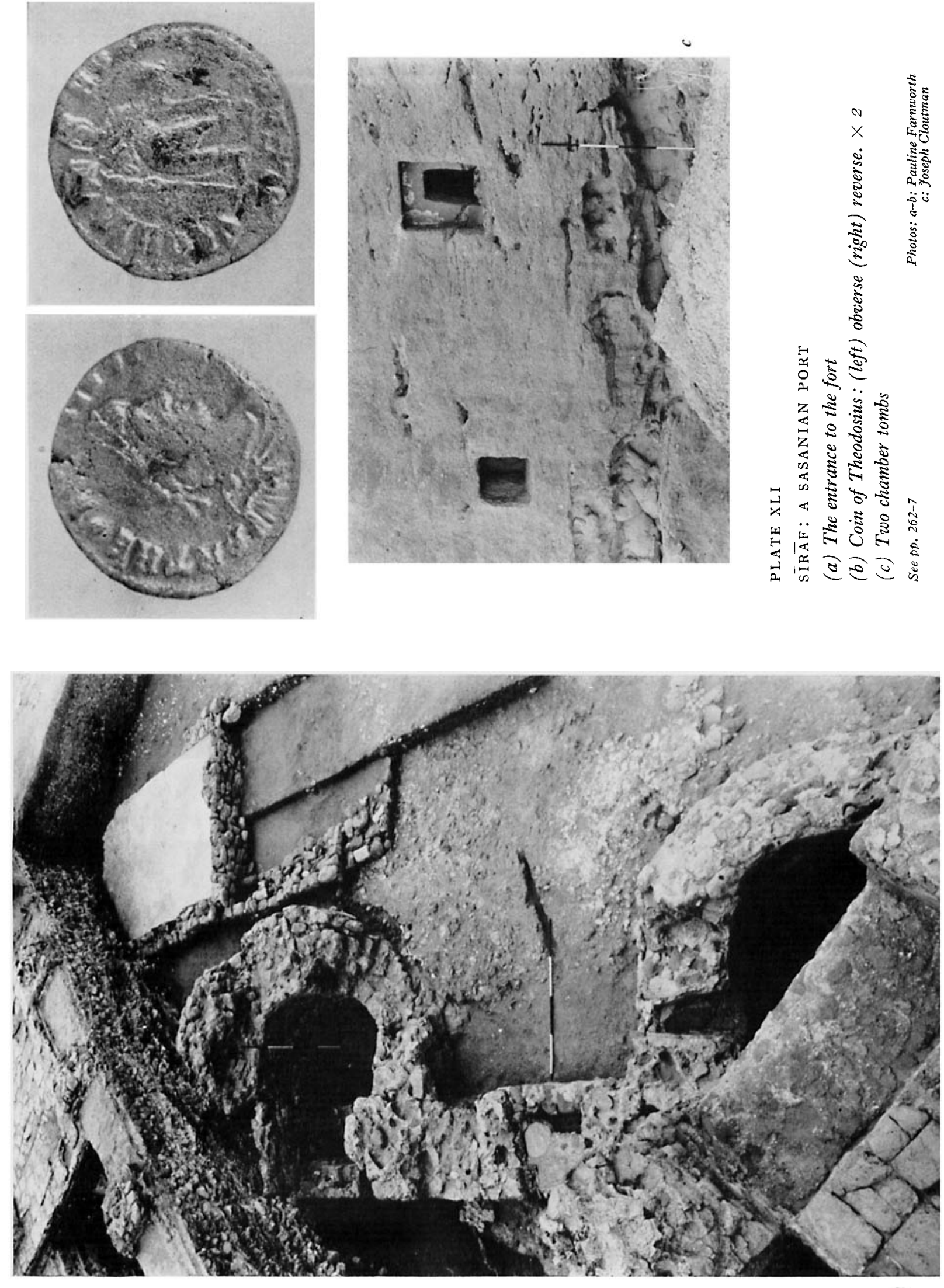